\title{
Genetic Relationships and Characterization of Persian Walnut (Juglans regia L.) Cultivars Using Restriction Fragment Length Polymorphisms (RFLPs)
}

\author{
R.G. Fjellstrom ${ }^{1}$, D.E. Parfitt, and G.H. McGranahan \\ Department of Pomology, University of California, Davis, CA 95616
}

\begin{abstract}
Additional index words. DNA, RFLP, cluster analysis, principal components
Abstract. RFLP markers were used to investigate genetic diversity among California walnut (Juglans regia) cultivars and germplasm collected worldwide. Sixteen of 21 RFLP markers were polymorphic in the 48 walnut accessions tested. RFLP markers were useful for identifying walnut cultivars. All genotypes were heterozygous at $\approx 20 \%$ of the loci for both California and worldwide germplasm. California walnut germplasm contained $60 \%$ of the worldwide allelic diversity. Cluster analysis of genetic distance between accessions and principal component analysis of allelic genotypes showed two major groups of walnut domestication. California germplasm was associated with germplasm from France, central Europe, and Iran and had less genotypic similarity with germplasm from Nepal, China, Korea, and Japan.
\end{abstract}

Juglans regia, the Persian or English walnut, is an important commercial crop in California where production has greatly benefited from the release of cultivars developed by the Univ. of California walnut breeding program. This breeding program was founded on crosses between late-season French selections ('Franquette' and 'Mayette') and laterally fruitful selections ('Chandler' and 'Vina'), which combined both traits (Forde, 1975; McGranahan and Forde, 1985). Lateral fruitfulness was derived from 'Payne', but was also found in 'Sharkey'. Because western Chinese walnut germplasm frequently exhibits lateral fruitfulness and French cultivars do not, it was suggested that 'Payne' and 'Sharkey' may have been derived from Chinese germplasm (Tulecke and McGranahan, 1994). Central Asian germplasm has also been used. 'Payne' was used in crosses with PI159568 from Afghanistan to produce 'Sunland' and 'Tulare'. Since a limited number of parents has been used to develop new California cultivars, an assessment of genetic variability in J. regia cultivars was needed to verify the availability of genetic diversity, which is required for continued crop improvement.

Little genetic information is available for this crop species despite its widespread commercial use, making genetic variability measurements difficult. Morphological variability, although readily recorded, can be an unreliable measure of genetic diversity because of the confounding effects of environment, pleiotropy, and the unknown genetic basis of most morphological attributes. Isozymes and RFLPs have advantages as genetic markers for appraising variability because 1) their codominant nature allows a plant genotype to be assayed directly and 2) they are relatively free from environmental effects. Arulsekar et al. $(1985,1986)$ identified isozyme loci using four enzyme systems (glucose phosphate isomerase, aspartate amino transferase, phosphoglucomutase, and esterase) in walnuts. To circumvent the potentially limiting number of isozyme loci available in walnuts, RFLP markers were developed to measure walnut genetic diversity. RFLPs have been

Received for publication 23 Aug. 1993. Accepted for publication 27 Dec. 1993. This research was funded in part by the California Agricultural Experiment Station, the California Genetic Resources Program, and the U.S. Dept. of AgricultureAgricultural Research Service. We thank Don Edwards, Univ. of California, Davis, Dept. of Pomology, for graphics production. The cost of publishing this paper was defrayed in part by the payment of page charges. Under postal regulations, this paper therefore must be hereby marked advertisement solely to indicate this fact. ${ }^{1}$ Present address: U.S. Dept. of Agriculture-Agricultural Research Service, National Forage Seed Production Research Center, Corvallis, OR 97331. successfully used to study genetic diversity in cross-pollinated and self-pollinated crop species (Brummer et al., 1991; Chase et al., 1991; Kesseli et al., 1991; Miller and Tanksley, 1990). In the current study, 22 walnut RFLP loci were used to determine the genetic diversity and relationships of 48 walnut accessions of diverse origins.

\section{Materials and Methods}

Germplasm. Walnut germplasm used for this study consisted of cultivars and selections from the Univ. of California, Davis, walnut breeding program; chance seedling cultivars; and plant introductions (Table 1). Trees were maintained at the Wolfskill Experimental Farm in Winters, Calif., at evaluation orchards in Davis, and as seedlings at the National Clonal Germplasm Repository (NCGR) greenhouses in Davis. Germplasm was classified into 12 groupings (Table 1) for combined cluster analysis. Carpathian germplasm is comprised of cold-hardy cultivars grown in the United States considered to have originated from eastern Europe. The germplasm classified as French germplasm are selections made in California from French lines.

DNA isolation. Leaves were collected from $48 \mathrm{~J}$. regia accessions (Table 1). Leaves were ground in liquid $\mathrm{N}$ and stored frozen at $-70 \mathrm{C}$ before DNA was isolated by a modification of the method of Doyle and Doyle (1987). Five grams of frozen leaves was added to $20 \mathrm{ml}$ of $60 \mathrm{C}$ preheated $2 \times$ CTAB buffer $(2 \%$ CTAB, $1 \%$ PVP, $1 \%$ b-mercaptoethanol, $0.1 \%$ sodium bisulfite, $1.4 \mathrm{M} \mathrm{NaCl}, 50 \mathrm{~mm}$ tris, 20 mm sodium EDTA, pH 8.0), and incubated at $60 \mathrm{C}$ for 30 $\mathrm{min}$. The aqueous solution was extracted with $20 \mathrm{ml} 24$ chloroform : 1 isoamyl alcohol and centrifuged for $10 \mathrm{~min}$ at $1800 \mathrm{rpm}$ in a bench-top centrifuge at $25 \mathrm{C}$, and the aqueous layer was retained. Fifteen milliliters of isopropanol was added to precipitate the nucleic acids. The precipitate was spooled and washed in $76 \%$ ethanol with $10 \mathrm{~mm}$ ammonium acetate. The nucleic acid precipitate was air-dried overnight, rehydrated in $1 \mathrm{ml}$ TE buffer $(10 \mathrm{~mm}$ tris, $1 \mathrm{~mm}$ EDTA, pH 8.0), digested with $10 \mu \mathrm{g}$ RNase at 37C for $1 \mathrm{~h}$, and precipitated with ethanol. The DNA precipitate was washed in $75 \%$ ethanol and dried overnight before rehydration in $200 \mu \mathrm{l}$ TE, pH 8.0. The DNA was quantified spectrophotometrically at $260 \mathrm{~nm}$ and visually in a $0.8 \%$ agarose gel stained with ethidium bromide containing lambda phage standards, with $\approx 25$ $\mu \mathrm{g} \cdot \mathrm{ml}^{-1} \mathrm{DNA}=1.0 \AA$ at $260 \mathrm{~nm}$.

RFLP detection. Six micrograms of walnut DNA was digested 
Table 1. Juglans regia accessions studied for RFLP diversity.

\begin{tabular}{|c|c|c|c|}
\hline Group & Accession & $\begin{array}{c}\text { Geographic } \\
\text { origin }\end{array}$ & Parentage $^{\mathrm{z}}$ \\
\hline$\overline{\text { Californian }}$ & Ashley & California & Unknown selection from California orchard \\
\hline Californian & Chandler & California & (C. Mayette x Payne) x (Sharkey x Marchetti) \\
\hline Californian & Chico & California & Sharkey x Marchetti \\
\hline Californian & Cisco & California & Meylan X (Payne x C. Mayette) \\
\hline Californian & Eureka & California & OP fron Persian or Kaghazi type from Iran \\
\hline Californian & Hartley & California & Franquette $\mathrm{x}$ Mayette cross? \\
\hline Californian & Howard & California & (C. Mayette x Payne) x (Sharkey x Marchetti) \\
\hline Californian & Payne & California & OP seedling possibly from French $x$ Chinese seedlings? \\
\hline Californian & Sharkey & California & Selected seedling from Chinese seed? \\
\hline Californian & Sunland & California & (Waterloo x Payne) x PI159568 \\
\hline Californian & Tulare & California & (Payne x Waterloo) x (Payne x PI159568) \\
\hline Californian & Vina & California & Franquette $x$ Payne \\
\hline Californian & S61-25 & California & (Hartley x Payne) x (C. Mayette x PI18256) \\
\hline Californian & S77-12 & California & Howard $\times[($ Waterloo $\times$ Payne $) \times($ Marchetti $\times$ Sharkey $)]$ \\
\hline Californian & S67-13 & California & (Payne x Waterloo) x (Payne x PI159568) \\
\hline French-Californian & Scharsch Franquette & California-France & Franquette seedling \\
\hline Southern Californian & Early Erhardt & Southern California & Erhardt selection \\
\hline Southern Californian & Placentia & Chile or China & OP seed \\
\hline Not used & Concha & Chile & OP selection from Chilean orchard \\
\hline Carpathian & Cascade & Washington & Russian type $x$ Manchurian (Manregian?) type \\
\hline Carpathian & Idaho & Idaho & \\
\hline Carpathian & North Platte & Nebraska & \\
\hline French & Conway Mayette & California-France & OP selection of Mayette \\
\hline French & Meylan & France & Seedling or clone from France \\
\hline French & XXX Mayette & California-France & OP selection of Mayette origin \\
\hline Central European & Sibisel Precose & Romania & \\
\hline Central European & Sibisel 41 & Romania & \\
\hline Central European & Alsoszentivani 117 & Hungary & \\
\hline Central European & Bulgaria 3 & Bulgaria & \\
\hline Central European & Geisenheim 139 & Germany & \\
\hline Central European & Purpurea & Germany & \\
\hline Afghani-Pakistani & NCGR $122.26, .27^{y}$ & Pakistan & \\
\hline Afghani-Pakistani & NCGR $254.1, .2^{\mathrm{y}}$ & Pakistan & \\
\hline Afghani-Pakistani & PI159568 & Afghanistan seedling & n from PI127460 \\
\hline Iranian & $0-20-1072$ & Iran & \\
\hline Nepal & NCGR 85.01 & Nepal & \\
\hline Indian & NCGR 102 & India & \\
\hline Russian & NCGR 155 & Russia & PI264362 (Kolobok OP seedling) \\
\hline Russian & NCGR 152 & Russia & PI264372 (Ideal OP seedling) \\
\hline Russian & NCGR 86.01 & Russia & \\
\hline Chinese & Beijing \#5 & China & \\
\hline Chinese & Xinjiang \#6 & China & \\
\hline Chinese & Xinjiang \#8 & China & \\
\hline Chinese & Yunnan \#1 & China & \\
\hline Chinese & PI18256 & China & \\
\hline Korean-Japanese & Sinensis \#7 & Japan & \\
\hline Korean-Japanese & NCGR 63.01 & Korea & \\
\hline Korean-Japanese & NCGR 146 & Korea & PI263512 \\
\hline
\end{tabular}

${ }^{\mathrm{z} C r o s s e s}$ giving rise to accession or variety giving rise to open-pollinated (OP) selection.

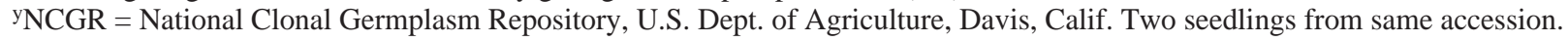

with 30 units of EcoRI or HindIII for $6 \mathrm{~h}$ and electrophoresed in $0.8 \%$ agarose with $1 \times$ TAE buffer $(45 \mathrm{~mm}$ tris acetate, 1 mM EDTA, $\mathrm{pH} 8.0$ ) for $18 \mathrm{~h}$ at $0.7 \mathrm{~V} / \mathrm{cm}$. Gels were stained with ethidium bromide to visualize the DNA and transferred (Southern, 1975) to $150 \times 150$-mm nylon membranes (Nytran, Schleicher \& Schuell, Keene, N.H.). Membranes were rinsed in 2x SSC ( $1 x$ SSC $=0.15$ $\mathrm{M} \mathrm{NaCl}, 0.015 \mathrm{M}$ sodium citrate, $\mathrm{pH} 7.0$ ), dried $2 \mathrm{~h}$ in a $65 \mathrm{C}$ oven, and stored dry at room temperature. Membranes were trimmed to
$140 \times 150 \mathrm{~mm}$, loaded into $30 \times 300-\mathrm{mm}$ hybridization bottles, prehybridized for $1 \mathrm{~h}$, and hybridized for 16 to $20 \mathrm{~h}$ at $65 \mathrm{C}$ according to the method of Church and Gilbert (1984). Thirty nanograms of insert DNA from 20 single-locus walnut probes (pFP01, 02, 03, 04, 06, 10, 11, 15, 17, 18, 24, 25, 26, 32, 34, 43, 45, 48, and 67) (unpublished data) and a wheat ribosomal gene (pTA71) (Gerlach and Bedbrook, 1979) were ${ }^{32} \mathrm{P}$ radiolabeled by the random priming method (Feinberg and Vogelstein, 1983), 
denatured by boiling and rapid cooling, and added directly to each hybridization tube. After hybridization, membranes were washed $2 \times 15 \mathrm{~min}$ in $2 \times \mathrm{SSC}, 0.1 \% \mathrm{SDS}$ at room temperature; $2 \times 15 \mathrm{~min}$ in $1 \times$ SSC, $0.1 \%$ SDS at $45 \mathrm{C}$; and $1 \times 30 \mathrm{~min}$ in $0.5 \mathrm{x} \mathrm{SSC}, 0.1 \%$ $\mathrm{SDS}$ at $65 \mathrm{C}$; rinsed in $2 \mathrm{x}$ SSC; blotted on paper towels; and autoradiographed on X-OMATAR film (Kodak, Rochester, N.Y.) at -70C using Cronex (Du Pont, Wilmington, Del.) intensifying screens for 1 to 5 days. Blots were stripped by soaking in $5 \mathrm{~mm}$ tris, $\mathrm{pH}$ 8.0, $0.5 \mathrm{~mm}$ EDTA, $\mathrm{pH} 8.0,0.01 \mathrm{x}$ Denhardts solution, and $0.05 \% \mathrm{Na}$-pyrophosphate at $65 \mathrm{C}$ for 30 to $60 \mathrm{~min}$; rinsed in $2 \mathrm{x}$ SSC; and stored dry. Blots were reprobed 5 to 10 times.

Genetic analysis. Allelic genotypes were scored for all loci except for those identified by pFP10. Because of the complex fragment pattern displayed by hybridizations with this probe, alleles could not be assigned and fragments were scored instead. Allelic frequency analysis of 20 loci (not including pFP10) was performed using the computer program BIOSYS-1 (Swofford and Selander, 1981) to generate genetic distance matrices (Nei, 1972), and perform unweighted pair group mean (UPGM) cluster analysis (average linkage clustering). Principal component analysis (PCA) of combined fragments from hybridizations with pFP10 and allelic data from all other hybridizations were analyzed using PC-SAS version 6.03, where the presence of a fragment was scored as 1 and its absence as 0 and alleles were given a score of 1 for each haploid copy present (e.g., AB individuals scored as 11, AA as 20, and $\mathrm{BB}$ as 02).

\section{Results}

Polymorphisms were observed for 16 of the 21 RFLP markers. All but one RFLP, from pFP10, could be assigned conventional single-locus allelic states. Even though mapping to a single locus, pFP10 gave a complicated banding pattern (Fig. 1), which prevented allelic state designations and could not be used to estimate heterozygosity levels. Because of the highly informative nature of this probe, with 24 different fragment patterns in J. regia, fragment data for this probe were included in the PCA. For the other loci, 46 alleles were identified.

The relatively high degree of RFLP heterozygosity in walnuts allowed us to identify walnut genotypes and their offspring. Even though a single RFLP marker could discriminate between two genotypes, seven markers were required to identify 49 genotypes in this study. The use of the highly polymorphic pFP10 marker would reduce the number needed to five markers. 'Ashley' and 'Payne' could not be separated, supporting the hypothesis that 'Ashley' is a bud sport of 'Payne'.

Apportioning the allelic diversity among their 13 geographic sources (Table 2) shows that, on average, each source contains $60 \%$ of the total allelic diversity found in the entire species. California germplasm contained $65 \%$ of the total allelic diversity, considerably higher than its French progenitor (with 50\%), but slightly less than Chinese, Afghani-Pakistani, central European, Russian, and Carpathian groups. Since California cultivars are

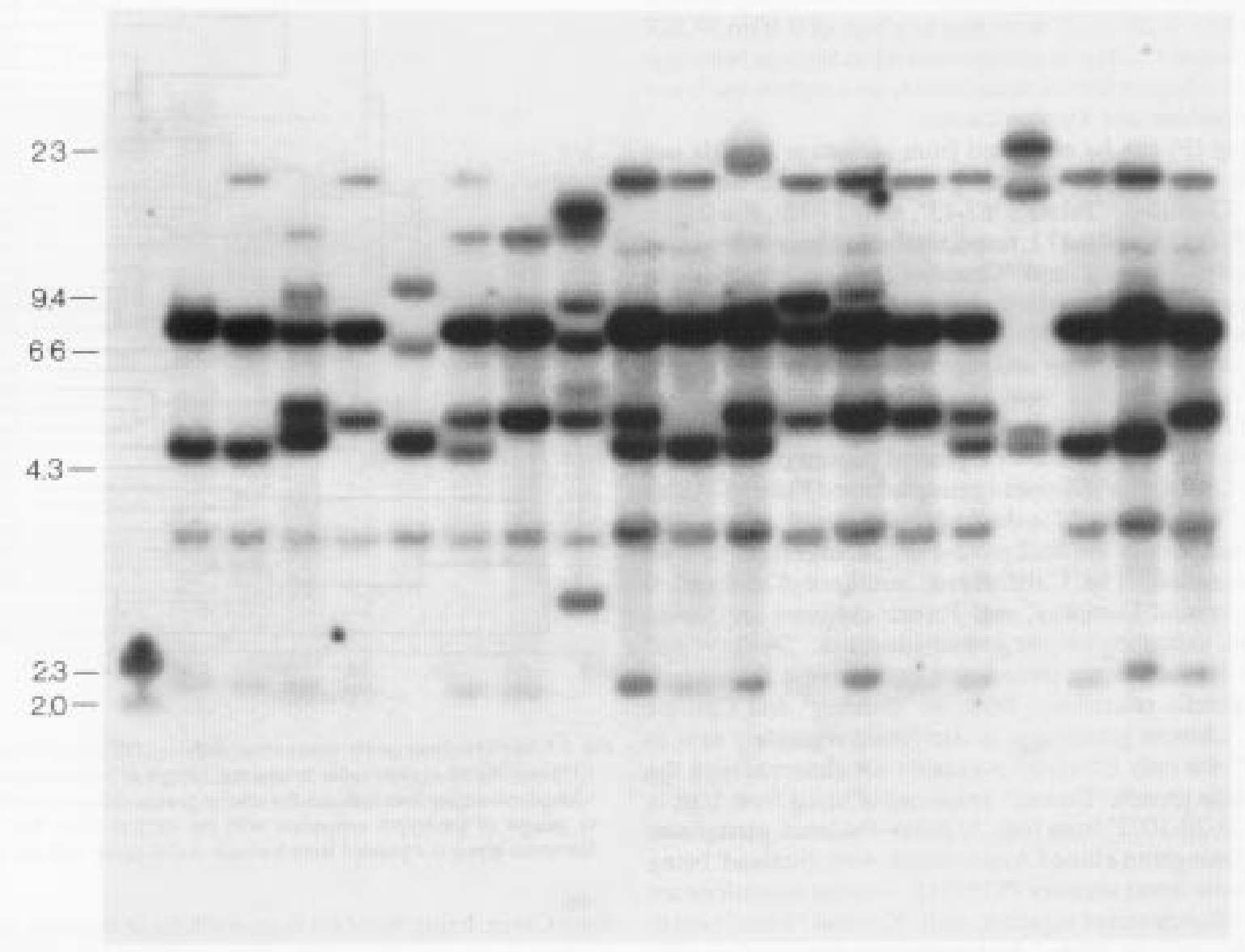

Fig. 1. Autoradiograph of 19 walnut genotypes digested with HindIII and hybridized with probe pFP10. Molecular length standards in kilobase pairs of DNA are presented on left. 
Table 2. Summary statistics for Juglans regia RFLP allelic genotypes at 20 RFLP loci.

\begin{tabular}{lcccc}
\hline \hline Origin & $\begin{array}{c}\text { No. of } \\
\text { accessions }\end{array}$ & $\begin{array}{c}\text { Mean } \\
\text { heterozygosity }\end{array}$ & $\begin{array}{c}\text { Proportion of } \\
\text { total alleles }\end{array}$ & $\begin{array}{c}\text { No. of unique } \\
\text { alleles }\end{array}$ \\
\hline California $^{\mathrm{z}}$ & 16 & 0.21 & 0.65 & 0 \\
Southern California & 2 & 0.19 & 0.54 & 0 \\
Carpathia & 3 & 0.27 & 0.67 & 1 \\
France $^{\mathrm{z}}$ & 4 & 0.21 & 0.52 & 0 \\
Central Europe $_{\text {Russia }}$ & 6 & 0.19 & 0.67 & 0 \\
Afghanistan-Pakistan & 3 & 0.23 & 0.67 & 0 \\
China & 5 & 0.16 & 0.70 & 2 \\
Korea-Japan & 5 & 0.18 & 0.70 & 2 \\
India & 3 & 0.18 & 0.65 & 1 \\
Nepal & 1 & 0.10 & 0.48 & 0.65 \\
Others & 1 & 0.50 & 0.48 & 2
\end{tabular}

ZIncludes 'Scharsch Franquette'.

${ }^{\mathrm{y}}$ Concha and O-20-1072.

wholly derived from introduced sources, it is not surprising that they contain no unique alleles (Table 2). Seven genotypes, primarily of Asian origin, contained unique alleles. Although the Carpathian genotypes were probably derived from eastern European germplasm, one unique allele at locus pFP43 was observed in 'North Platte' (Lindgreen and Gustafson, 1982). The small number of cultivars tested from central Europe and Russia probably accounted for the absence of this allele in the other European sources. Only $26 \%$ of the alleles was found in every source region and $37 \%$ was found in all but one source region. The average heterozygosity level among all genotypes was 0.197 , ranging from a low of 0.05 in ' $0-20-1072$ ' from Iran to a high of 0.50 in NCGR 85.01 from Nepal. California germplasm had an average heterozygosity of 0.21 , a higher level than for most source regions but lower than for Carpathian and Russian sources.

Inbreeding $(\mathrm{F})$ can be estimated from parentage records and ranges from 0 to 0.172 . For most genotypes, $\mathrm{F}=0$, while for 'Howard', 'Chandler', 'Tulare', '67-13', and '77-12', F = 0.063, $0.063,0.125,0.125$, and 0.172 , respectively. In terms of retaining heterozygosity, 'Howard' and 'Chandler' had no reductions in their heterozygosity compared to their parental lines, while 'Tulare', ' $67-13$ ', and ' $77-12$ ' had $33.3 \%, 11.1 \%$, and $30.8 \%$ reductions in their levels of heterozygosity and seemed to agree with expected inbreeding estimates.

The UPGM cluster analysis of genetic distance (Nei, 1972) between cultivars (Fig. 2) shows a general pattern of separation between the Californian-European germplasm and Russian-Asian germplasm. 'Payne' is found in the first cluster joined, as would be expected since it is in the background of the largest number of cultivars sampled. The Californian, southern Californian, Carpathian, central European, and French cultivars are joined together first, indicating similar genetic identities. 'Sharkey' and some of its derivatives are joined near two Chinese accessions, indicating genetic relatedness between 'Sharkey' and Chinese germplasm. Chinese germplasm is also found separately next to 'Bulgaria 3', the only European accession not clustered with the Euro-American groups. 'Eureka', suspected of being from Iran, is joined with '0-20-1072' from Iran. Afghani-Pakistani germplasm is scattered throughout a broad Asian cluster, with 'Sunland' being found next to its direct ancestor PI159568. Russian accessions are found somewhat clustered together, with 'Kolobok' found next to the Carpathian cultivar 'Idaho', both being cold-tolerant lines. The Sinensis types from Korea and Japan are found with the Nepal and Indian accessions, far from most other germplasm. 'Yunnan \#1'

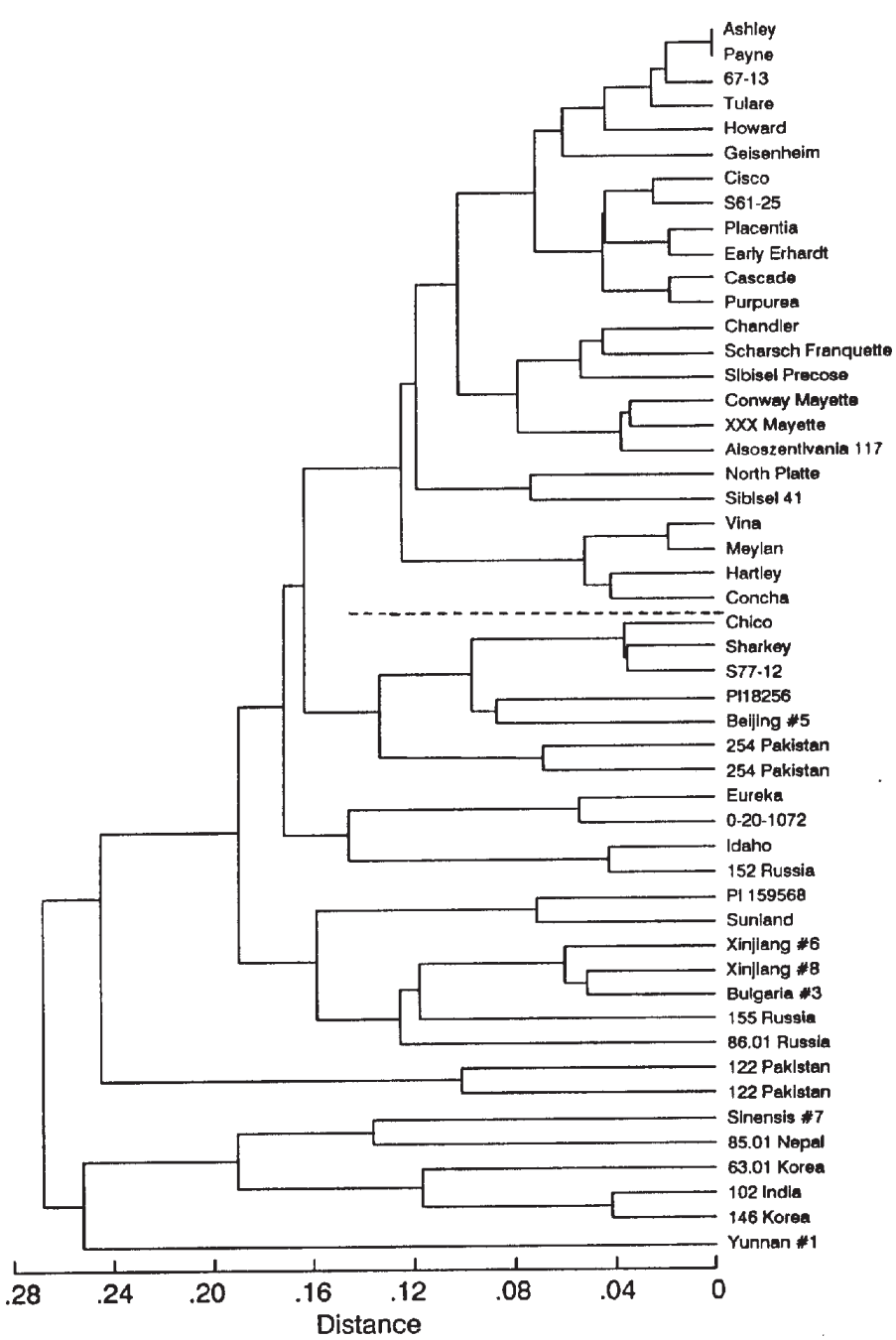

Fig. 2. Unweighted pair group mean cluster analysis of RFLP genetic distance (Nei, 1972) among 48 Juglans regia accessions. Length of horizontal lines joined by vertical connecting lines indicates the relative genetic differences of the genotypes or groups of genotypes connected with the vertical lines. The CalifornianEuropean group is separated from Russian-Asian group with the dotted line.

from China, being fixed for unique alleles at two loci, is found the farthest from any cluster. This type of Yunnan walnut was once classified as a separate species (J. sigilata) (Dode, 1909) because of its unique leaf and nut morphology. When the accessions are 


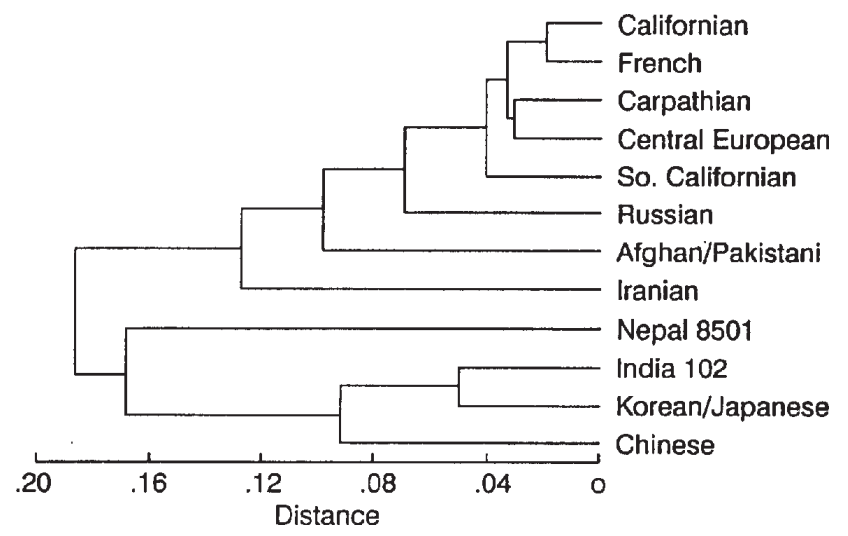

Fig. 3. Uweighted pair group mean cluster analysis of RFLP genetic distance (Nei, 1972) among 12 source groups of Juglans regia genotypes. regrouped into 12 sources, placing 'Scharsh Franquette' with French lines and 'Eureka' with '0-20-1072' from Iran, and their genetic distances are recalculated and separated by cluster analysis, two major cluster groups can be identified (Fig. 3). One group extends from Europe to central Asia; the other group includes the south and east Asian region.

PCA of allelic genotypes among the cultivars showed that only $17.8 \%$ of the variation could be accounted for by the first PC, $11.2 \%$ by the second PC, $9.4 \%$ by the third PC, and only $75.0 \%$ by the first eight PCs. Although two pairs of loci, pFP03/34 and pFP24/67, map only $1.6 \mathrm{cM}$ apart on linkage groups 4 and 11 , respectively, of the walnut genome (unpublished data), there were no allelic correlations between any of the RFLP loci. A threedimensional plot of the genotypes against the first three PCs (Fig. 4) divides most Asian accessions from the Euro-American accessions, but otherwise separates few members of this latter group into

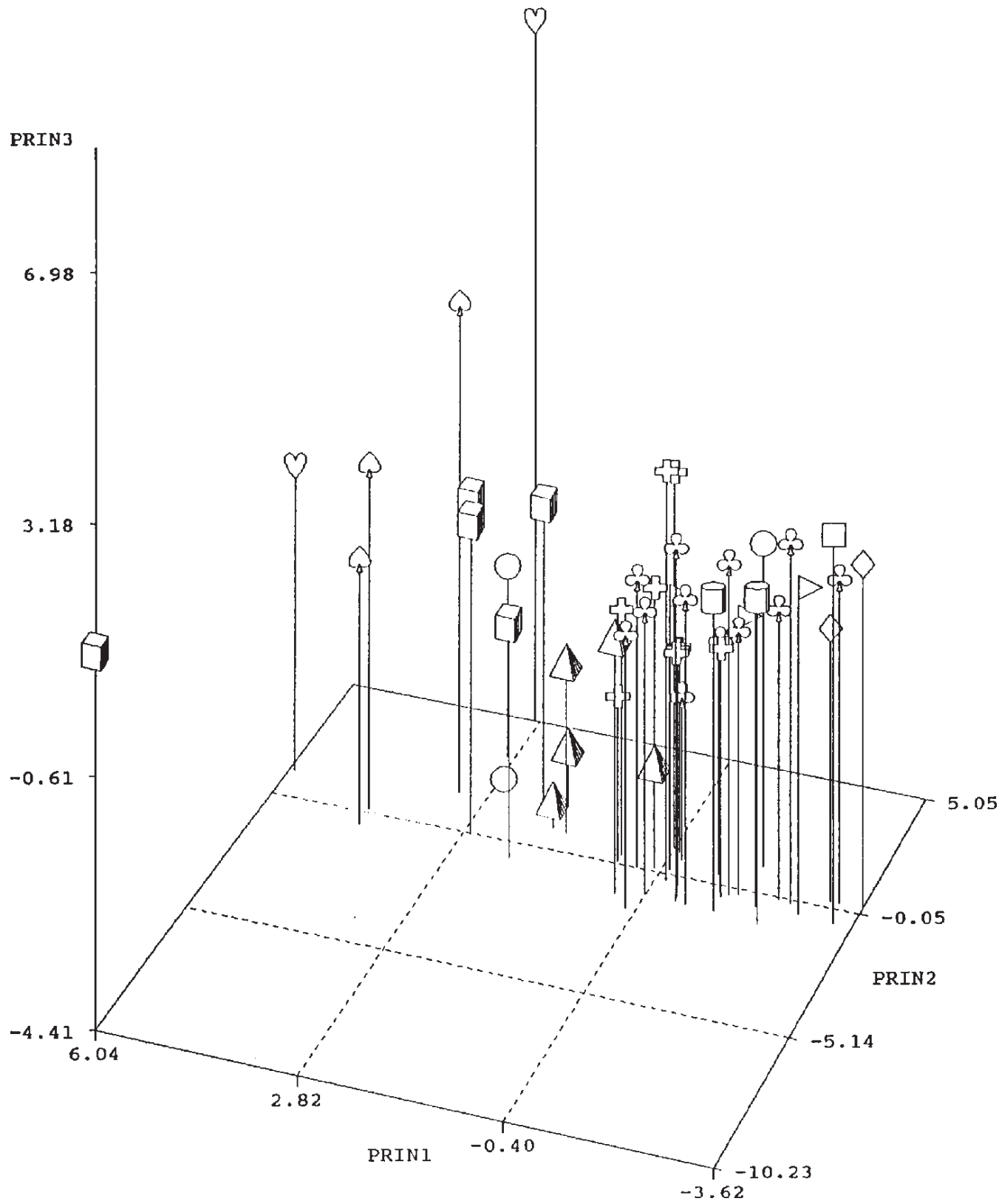

Fig. 4. Plot of Juglans regia accessions coded by geographic origin against the first three principal components of RFLP allelic genotypes. Clubs $=$ California, flags $=$ France, crosses $=$ central Europe and Carpathia, diamonds $=$ Iran, squares $=$ Concha, cylinders $=$ southern California, pyramids = Afghanistan - Pakistan, circles $=$ Russia, cubes $=$ China, spades $=$ Korea-Japan, hearts $=$ India and Nepal. 
any obvious pattern. Groupings can be seen for germplasm from Korea-Japan (sometimes referred to as J. sinensis), China, Afghanistan-Pakistan, France, and Iran. Carpathian-central European and California germplasm overlapped each other and the French and Afghani-Pakistani germplasm, which could be expected because of their shared backgrounds. Like the cluster analysis, it can also be seen that two of the Russian accessions group with east Asian germplasm and one accession groups with more western germplasm. Inspection of additional PCs did not appreciably increase the differentiation of germplasm groups, but only changed the relative spread of the same groups previously identified. Two of the Russian accessions are found in the east Asian group and one in the Euro-American group. Two Pakistani accessions are found in the east Asian group and one is found in the more western group.

\section{Discussion}

This RFLP study has provided comparative information on California walnut germplasm with respect to foreign germplasm and has illuminated previously untested hypotheses. The California germplasm pool seems to be as diverse as most other walnut germplasm pools and does not seem to have significantly reduced genetic diversity levels. However, by examining the considerable amount of allelic diversity available in other germplasm sources, untapped genetic diversity may be found, particularly from eastern Asia. There is no general loss of heterozygosity in California walnut germplasm compared to foreign germplasm, except in the few cases where heterozygosity loss was expected from increased inbreeding. Selection '77-12', which has the highest F value (based on ancestry), but not the lowest amount of RFLP heterozygosity, is a relatively weak tree, which could be expected from inbreeding in this normally outcrossed species. Trees that have the lowest amount of RFLP heterozygosity are not weak trees, suggesting that these loci are not linked to deleterious recessive alleles.

The RFLP variation identified in this study is also useful for identifying cultivars. The minimum number of probes needed to tell 49 genotypes apart is seven, the same number predicted by the equation $P=3^{\mathrm{k}} ! / 3^{\mathrm{kn}}\left(3^{\mathrm{k}}-\mathrm{n}\right)$ !, where $P=$ probability of discriminating $\mathrm{n}$ cultivars and $\mathrm{k}=$ the number of loci with two alleles per locus (Parfitt, 1989; Soller and Beckman, 1983). Variations on the number of probes needed will depend on the allelic variability in the populations surveyed. More probes would be needed to separate many closely related genotypes. Fewer probes would be needed where more than two alleles per locus are present. Because of the time involved in Southern hybridization analyses (Southern, 1975), it could be more efficient to use isozyme or randomly amplified polymorphic DNA (RAPD) (Williams et al., 1990) marker analysis instead of RFLP analysis for routinely fingerprinting cultivars. Nevertheless, these RFLP probes have effectively identified parentage of walnut offspring (Aly et al., 1992) and can overcome the problems of low polymorphism levels in isozyme loci and the potential unreliability of RAPD markers.

Cluster analysis of the genetic distance among accessions grouped most accessions within the same source together, but also identified some additional groups of interest. 'Sharkey' was grouped with Chinese accessions, affirming its Chinese origins, while 'Payne' seems to be of western origin. These results also suggest that the lateral-bearing trait found in 'Payne' and 'Sharkey' had unrelated origins from Europe and Asia. 'Bulgaria \#3' is apparently derived from Chinese germplasm. The proposed Iranian origin of 'Eureka' (Tulecke and McGranahan, 1994) is supported by its grouping with '0-20-1072' from Iran.

Cluster analysis of the 12 germplasm sources placed the California germplasm near the French and placed the Carpathian germplasm near the central European. The two main clusters identified indicate that most European germplasm originated from Iran and the Asian germplasm originated near the Himalaya mountain range. These hypotheses are supported from historical accounts (McGranahan and Leslie, 1991) that the European germplasm was initially brought via Greek and Roman trade from Persia and that Chinese germplasm came from areas to the west of China. PCA also divided the 48 accessions into these two main groups, with Iranian germplasm found on one extreme of the first PC and east Asian germplasm on the other margin. A small number of PCs could not explain most allelic variation seen, as would be expected if there is an absence of linkage disequilibrium among the RFLP loci. Even though a few of the RFLP loci are closely linked, the lack of allelic correlations between these loci implies that there has been no selection over time to retain allelic linkage disequilibrium. A similar lack of allelic correlation between closely linked RFLP loci was reported in Triticum (Lubbers et al., 1991).

The concept of core collections, for which the number of accessions within germplasm collections is condensed but still represents the total species diversity (Frankel and Brown, 1984), can be empirically evaluated with the results from this experiment. The characters in this study had minimal genetic relatedness and were assumed to be unlinked to selected characteristics. Thus, these markers can be considered to represent the actual variation for these accessions. Selecting $10 \%$ of accessions by randomly sampling each of five RFLP geographic clustering groups (California-France, central Europe-Carpathia, China, Korea-Japan, and other Asia) will on average retain $78.1 \%$ of the species allelic diversity, which is well within the $70 \%$ objective goal (Brown, 1989) of core collections. However, there is a considerable amount of phenotypic variability within these clustering groups, and a single accession $(\approx 10 \%)$ from each of these groups does not sufficiently reflect the expressed genetic variability found in that group. Also, because many J. regia plant introductions, especially wild germplasm accessions, were not included in this study (as it focused primarily on California germplasm), there is a high probability that there is considerably more allelic diversity within this species than was detected in this study.

\section{Literature Cited}

Aly, A.M.M., R.G. Fjellstrom, G.H. McGranahan, and D.E. Parfitt. 1992. Origin of walnut somatic embryos determined by RFLP and isozyme analysis. HortScience 27:61-63.

Arulsekar, S., D.E. Parfitt, and G.H. McGranahan. 1985. Isozyme gene markers in Juglans species. J. Hered. 76:103-106.

Arulsekar, S., G.H. McGranahan, and D.E. Parfitt. 1986. Inheritance of phosphoglucomutase and esterase isozymes in Persian walnut. J. Hered. 77:220-221.

Brown, A.H.D. 1989. Core collections: A practical approach to genetic resources management. Genome 31:818-824.

Brummer, E.C., G. Kochert, and J.H. Bouton. 1991. RFLP variation in diploid and tetraploid alfalfa. Theoretical Applied Genet. 83:89-96.

Chase, C.D., V.M. Ortega, and C.E. Vallejos. 1991. DNA restriction fragment length polymorphisms correlate with isozyme diversity in Phaseolus vulgaris L. Theoretical Applied Genet. 81:806-811.

Church, G.M. and W. Gilbert. 1984. Genomic sequencing. Proc. Natl. Acad. Sci. USA 81:1991-1995.

Dode, L.A. 1909. Contribution to the study of the genus Juglans. Bul. Soc. Dendrol. France 11:22-90, 12:165-215.

Doyle, J.J. and J.L. Doyle. 1987. A rapid DNA isolation procedure for small quantities of fresh leaf tissue. Phytochem. Bul. 191:11-15. 
Feinberg, A.P. and B. Vogelstein. 1983. A technique for radiolabelling DNA restriction fragments to a high specific activity. Anal. Biochem. 132:6-13.

Forde, H.I. 1975. Walnuts, p. 84-97. In: J. Janick and J.N. Moore (eds.). Advances in fruit breeding. Purdue Univ. Press, West Lafayette, Ind.

Frankel, O.H. and A.H.D. Brown. 1984. Plant genetic resources today: A critical appraisal, p. 249-256. In: J.H.W. Holden and J.T. Williams (eds.). Crop genetic resources: conservation and evaluation. Intl. Board Plant Genet. Resources, George, Allen, and Unwin, London.

Gerlach, W.L. and J.R. Bedbrook. 1979. Cloning and characterization of ribosomal RNA genes from wheat and barley. Nucleic Acids Res. 7:1869-1885.

Kesseli, R., O. Ochoa, and R. Michelmore. 1991. Variation at RFLP loci in Lactuca spp. and origin of cultivated lettuce (L. sativa). Genome 34:430-436.

Lindgreen, D.T. and W.A. Gustafson. 1982. 'North Platte' Carpathian walnut. 73rd Northern Nut Growers Annu. Rpt. p. 124-125.

Lubbers, E.L., K.S. Gill, T.S. Cox, and B.S. Gill. 1991. Variation of molecular markers among geographically diverse accessions of Triticum tauschii. Genome 34:354-361.

McGranahan, G.H. and H.I. Forde. 1985. Genetic improvement, p. 8-12. In: D.E. Ramos (ed.). Walnut orchard management. Univ. Calif. Div. Agr. Natural Resources, Oakland.

McGranahan, G. and C. Leslie. 1991. Walnuts (Juglans), p. 907-951. In: J.N. Moore and J.R. Ballington (eds.). Genetic resources of temperate fruit and nut crops. vol 2. Intl. Soc. Hort. Sci., Wageningen.

Miller, J.C. and S.D. Tanksley. 1990. RFLP analysis of phylogenetic relationships and genetic variation in the genus Lycopersicon. Theoretical Applied Genet. 80:437-448.

Nei, M. 1972. Genetic distance between populations. Amer. Naturalist 106:283-292.

Parfitt, D.E. 1989. The use of isozyme electrophoresis for ampelography and evaluation of genetic diversity in Vitis vinifera L. Rivista Viticult. Enol. 1:7-14.

Soller, M. and J.S. Beckman. 1983. Genetic polymorphism in varietal identification and genetic improvement. Theoretical Applied Genet. 67:25-33.

Southern, E.M. 1975. Detection of specific sequences among DNA fragments separated by gel electrophoresis. J. Mol. Biol. 98:503-517.

Swofford, D.L. and R.B. Selander. 1981. BIOSYS-1: A FORTRAN program for the comprehensive analysis of electrophoretic data in population genetics and systematics. J. Hered. 72:281-283.

Tulecke, W. and G.H. McGranahan. 1994. The walnut germplasm collection at the University of California, Davis: A description of the collections and a history of the breeding program of Eugene F. Serr and H.I. Forde. Genet. Resources Conservation Program, Univ. of California, Davis, Rpt. 13.

Williams, J.G.K., A.R. Kubelik, K.J. Livak, J.A. Rafalski, and S.V. Tingey. 1990. DNA polymorphisms amplified by arbitrary primers are useful as genetic markers. Nucleic Acids Res. 18:6531-6535. 